Journal of Polytechnic POLITENAK DERGISI

\section{POLITEKNIK DERGISI}

JOURNAL of POLYTECHNIC

\title{
Rüzgâr güicü tahminlerinin önemi: Türkiye elektrik piyasasında bir uygulama
}

\section{The importance of wind power forecasts: a case study in Turkish electricity market}

Yazar(lar) (Author(s)): Fatih KARIK, Adnan SÖZEN, Muhammed Mustafa IZGEÇ

Bu makaleye șu șekilde atıfta bulunabilirsiniz (To cite to this article): Karık F., Sözen A. ve İzgeç M. M., "Rüzgâr gücü tahminlerinin önemi: Türkiye elektrik piyasasında bir uygulama", Politeknik Dergisi, 20(4): 851-861, (2017).

Erişim linki (To link to this article): http://dergipark.gov.tr/politeknik/archive DOI: 10.2339/politeknik.369038 


\title{
Rüzgâr Gücü Tahminlerinin Önemi: Türkiye Elektrik Piyasasında Bir Uygulama
}

\author{
Araştırma Makalesi / Research Article \\ Fatih KARIK ${ }^{*}$, Adnan SÖZEN² ${ }^{2}$ Muhammed Mustafa IZGEÇ³ \\ ${ }^{1}$ T.C. Enerji ve Tabii Kaynaklar Bakanlığı, Yenilenebilir Enerji Genel Müdürlüğü, Ankara, Türkiye. \\ ${ }^{2}$ Gazi Üniversitesi, Teknoloji Fakültesi, Enerji Sistemleri Mühendisliği Bölümü, Ankara, Türkiye. \\ ${ }^{3}$ T.C. Enerji Piyasası Düzenleme Kurumu, Ankara, Türkiye. \\ (Geliş/Received : 20.05.2016 ; Kabul/Accepted : 06.06.2016)
}

\begin{abstract}
ÖZ
Doğal enerji kaynaklarını verimli ve çevreye duyarlı şekilde değerlendirerek ülke refahına en yüksek katkıyı sağlamak ve bunu sürdürülebilir kılmak günümüzün en büyük hedefleri arasında yer almaktadır. Bu çerçevede, Türkiye'nin enerjide dışa bağımlılığını azaltması için yenilenebilir enerji kaynaklarından faydalanması çok önemli bir yere sahiptir. Türkiye, Cumhuriyetin kuruluşunun 100. yılı olan 2023'ü kendisi için hem enerji hem de ekonomi göstergeleri bakımından hedef bir y1l olarak belirlemiştir. Bu hedefler içerisinde 2023 yılında yenilenebilir enerji kaynaklarından en az \%30 elektrik üretimi ve $20 \mathrm{GW}$ rüzgâr enerjisi kurulu gücü planlanmaktadır. $\mathrm{Bu}$ hedeflere ulaşırken elektrik piyasasının doğru işletilmesi elektrik arz-talep dengesi, düşük maliyetler ve yatırımlar açısından önemli bir yere sahiptir. Rüzgârdan elektrik üretimi profili değişken bir yapıya sahiptir ve elektrik piyasasında olumsuz etkilere neden olabilmektedir. Bu etkinin azaltılması için rüzgâr enerjisi santrallerinin elektrik piyasasına sunduğu enerji üretim tahminleri önemli bir yere sahiptir. Hem santral sahibi hem de sistem işletmecisi açısından doğruluk oranı yüksek tahminin değeri büyüktür. Bu çalışmada, rüzgâr enerjisi tahminlerinin piyasa geliri açısından önemini gösteren gün öncesi piyasası (GÖP) analizleri yenilenebilir enerji destekleme mekanizması (YEKDEM) ile karşılaştırılmalı olarak yapılmıştır.
\end{abstract}

Anahtar Kelimeler: Rüzgâr enerjisi tahmini, yenilenebilir enerji, Türkiye elektrik piyasası.

\section{The Importance of Wind Power Forecasts: A Case Study in Turkish Electricity Market}

\begin{abstract}
Today, providing the highest contribution to national welfare by utilizing natural energy resources in the most efficient and environmentally-conscious manner is one of the biggest targets. In this framework, the utilization of domestic renewable energy sources is crucial importance for Turkey to decrease its energy dependence on foreign supplies. Turkey has determined the target year as 2023, the 100th anniversary of the foundation of Republic, in terms of both energy and economic indicators. The share of renewable energy sources in electricity generation is at least $\% 30$ and the planned capacity is $20 \mathrm{GW}$ of installed wind power in 2023. For reaching these targets, it is important to be operated the electricity market in a proper way in terms of the electricity supply-demand balance, low costs and investments. The electricity generation from wind has a variable profile and can cause negative effects in the electricity market. It is important to offer the energy production forecasts of wind power plants to the electricity market for reducing these effects. The forecasts with high accuracy is significant for both plant owner and transmission operator. In this study, the analysis of day ahead market (GÖP) which shows the importance of wind power forecast in terms of market revenue is conducted in comparison with renewable energy support mechanism (YEKDEM).
\end{abstract}

Keywords: Wind energy forecast, renewable energy, Turkish electricity market.

\section{GİRIS (INTRODUCTION)}

Sürekli değişen ve gelişen teknolojiye bağlı olarak artan enerji ihtiyacı insanlığın en büyük problemlerinden biri haline gelmiştir. Geçmişten günümüze kadar yoğun olarak kullanılan fosil enerji kaynaklarının azalması, fiyatlarının yükselmesi (veya değişkenliği) ve sebep olduğu sera gazlarının zaman geçtikçe dünya doğasına ve atmosferine verdiği zararlardan ötürü dünya ülkeleri sağllklı, temiz ve sürdürülebilir enerji kaynakları olarak nitelendirilen yenilenebilir enerji kaynaklarına doğru hızlı bir yönelişe geçmek durumunda kalmıştır. Yenilenebilir

*Sorumlu Yazar (Corresponding Author)

e-posta :fkarik@yegm.gov.tr enerji kaynakları; kanunda hidrolik, rüzgâr, güneş, jeotermal, biyokütleden elde edilen gaz (çöp gazı dahil), dalga, akıntı enerjisi ve gel-git gibi fosil olmayan enerji kaynakları olarak tanımlanmaktadır [1]. Uluslararası Enerji Ajansı (UEA) verilerine göre 2013 yılında dünyada toplam elektrik üretimi $23406 \mathrm{TWh}$ gerçekleşmiş olup, kaynaklara göre dağılımı Şekil 1'de görülmektedir. Hidrolik enerji hariç yenilenebilir kaynakların içinde en yüksek pay, Şekil 1'de gösterildiği gibi \%2.7 ile rüzgâr enerjisine aittir [2].

Rüzgâr enerjisi dünyada yenilenebilir enerji kaynakları arasında en hızlı gelişime sahip olan ve en fazla yatııım yapılan enerji türüdür. Küresel Rüzgâr Enerjisi Konseyi verilerine göre dünyada 2015 yllı sonu itibariyle toplam 


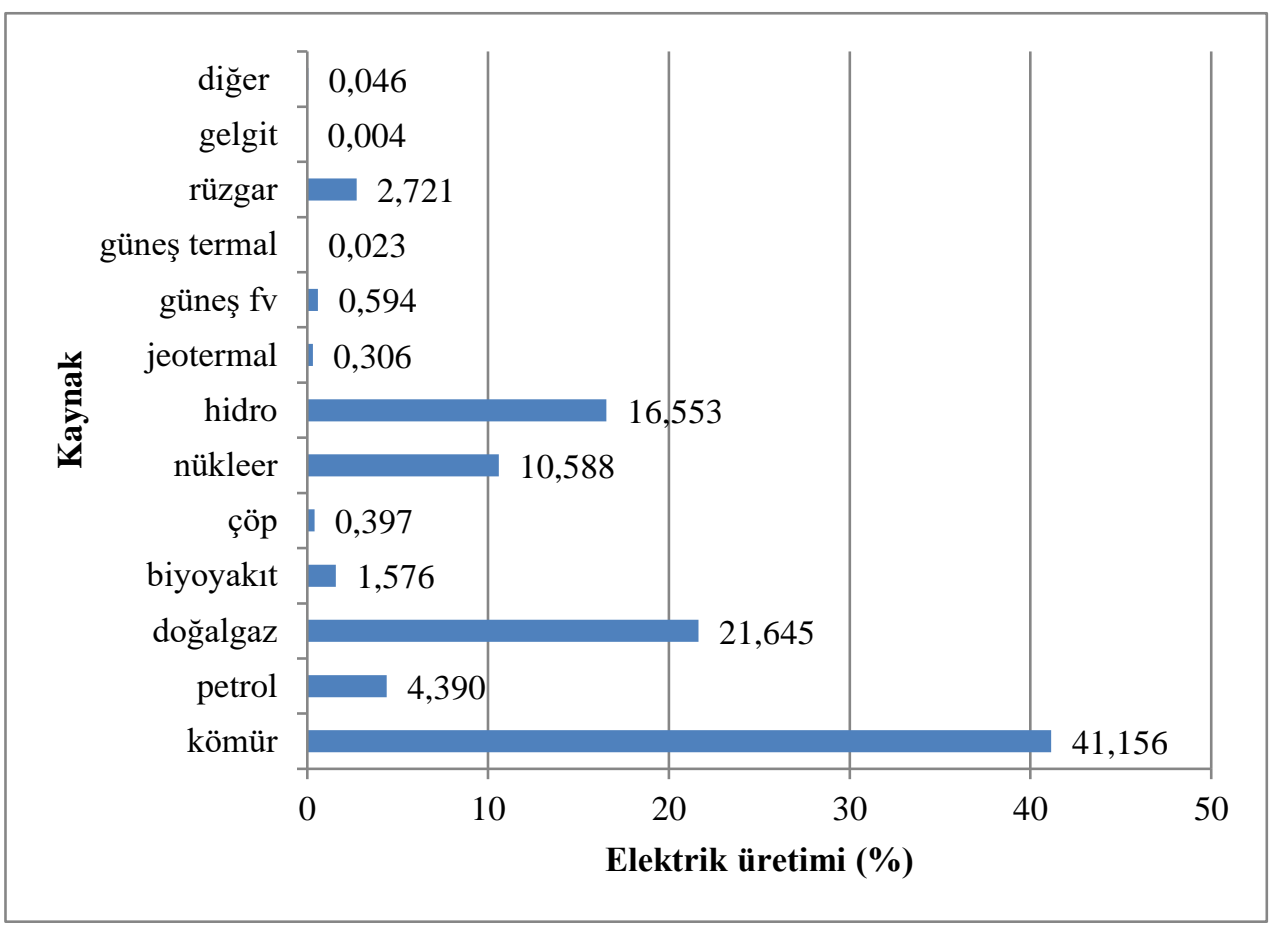

Şekil 1. Dünyada elektrik üretiminin kaynak türlerine göre dağılımı (Electricity generation by sources in the world)

rüzgâr kurulu gücü 432.4 GW seviyesine ulaşmış olup, ilk beş sırayı Çin (145.1 GW), ABD (74.4 GW), Almanya (44.9 GW), Hindistan $(25.0 \mathrm{GW})$ ve İspanya $(23.0$ GW) ülkeleri oluşturmaktadır. Türkiye, 2015 yılında kurulu güçte 956 MW artış göstererek dünyada bu yıl için artış bakımından ilk on ülke arasına girmiştir [3].

Her yıl artan nüfusu ve büyüyen ekonomisi ile Türkiye gelişen bir ülkedir. Bu gelişmeye paralel olarak enerjiye olan talebi de yıldan yıla artmaktadır. 2000-2013 yılları arası İktisadi İşbirliği ve Kalkınma Teşkilatı-Organisation for Economic Co-operation and Development (OECD) ülkelerinin toplam nihai enerji tüketimi yılda ortalama \%0.03 artmış olup, Türkiye için bu değer \%3.25 olmuştur. Toplam elektrik tüketimi değerlerine bakılacak olursa 2000-2014 yılları arası OECD ülkelerinin toplamı y1lda ortalama \%0.69 artmış olup, Türkiye için bu değer \%5.48 olmuştur. Bu rakamlar Türkiye'nin OECD ortalamasının bir hayli üzerinde olduğunu göstermektedir [2]. Ancak, 2014 yılında Türkiye'de toplam birincil enerji arzı içerisinde fosil yakıtlar için \%82 oranında ithalat gerçekleştirilmiştir [4].

Türkiye'de 2015 yılında toplam elektrik tüketimi 264 TWh olarak gerçekleşmiştir. Elektrik üretiminde kamunun payı \%21.3 ve özel sektörün payı \%78.7 olmuştur. Ayrıca, 2015 yılı sonu itibariyle elektrik kurulu gücü 73.1 GW'ye ulaşmıştır. Yine aynı yılda elektrik üretiminin $\% 68$ 'i fosil yakıtlardan ve $\% 32$ 'si yenilenebilir enerji kaynaklarından gerçekleşmiştir [5]. Halbuki, Türkiye'de hidrolik enerji hariç 100.6 GW yenilenebilir enerji kurulu güç potansiyeli bulunmaktadır [6]. Türkiye, bu yüksek miktardaki yenilenebilir enerji potansiyelini kullanabilirse enerjide dışa bağımlılık oranı önemli miktarda azalacaktır.
Yapılan araştırmalarda rüzgâr enerjisi politikaları ve elektrik piyasaları ile ilgili birbirinden bağımsız birçok çalışma yapılmasına rağmen, Türkiye'ye yönelik güncel düzenlemeler çerçevesinde rüzgâr enerjisi santrallerinin elektrik piyasasındaki faaliyetlerinin ve rüzgâr enerjisi tahminlerinin elektrik piyasası ile ilişkileri üzerine bir çalışmanın olmadığı görülmüştür. Bu çalışmada, Türkiye'de ilk rüzgâr türbinin kurulmasından itibaren rüzgâr enerjisinin gelişimi, rüzgâr enerjisi tahminleri ve elektrik piyasası incelenmiş olup, tahminlerin etkileri araştırılmıştır. Çalışmada ikinci bölümde, Türkiye'deki rüzgâr enerjisi santralleri (RES)'nin genel durumları ve enerji potansiyeli hakkında bilgiler verilmiştir. Üçüncü bölümde, rüzgâr enerjisi tahminlerinin öneminden ve Türkiye'de bu alanda geliştirilen projeden bahsedilmiştir. Dördüncü bölümde, Türkiye elektrik piyasası yapısı anlatılmıştır. Ayrıca, elektrik piyasası faaliyetleriyle ilgili olan YEKDEM hakkında bilgiler verilmiştir. Beşinci bölümde, rüzgâr enerjisi tahminlerine dayalı olmak üzere YEKDEM ile karşılaştırılmalı örnek bir elektrik piyasası uygulaması gerçekleştirilmiştir. Sonuç bölümünde ise analizlerden elde edilen başlıca çıkarımlar sunulmuştur.

\section{TÜRKIYE'DE RÜZGÂR ENERJISINIIN GELİ- ŞiMi (DEVELOPMENT OF WIND ENERGY IN TURKEY)}

Türkiye'de ilk rüzgâr türbini 1986 y1lında 55 kW gücünde Çeşme'de kurulmuştur. 1986'dan 1996'ya kadarki süreçte bir gelişme gösterilememiştir. 1998'te 1.5 MW gücünde ilk RES İzmir, Alaçatı'da kurulmuştur [7]. Türkiye'de rüzgâr enerjisi yatırımları, 1998 yılından itibaren, daha çok küçük ölçekli olmak üzere 1984'te kabul edilen 3096 sayılı kanunla Yap İşlet Devret (YID) modeli ile 
artmaya başlamıştır. Daha sonra 4628 [8] ve 6446 [9] sayılı Elektrik Piyasası Kanunları ile özel teşebbüs, lisanslı RES'leri kurmuştur. Özellikle 2005 yılından sonra 5346 sayıl1 "Yenilenebilir Enerji Kaynaklarının Elektrik Enerjisi Üretimi Amaçlı Kullanımına İlişkin” Kanun [1] çıkarıldıktan sonra rüzgâr kurulu gücünde ciddi artışlar gözlenmiştir.

31 Mart 2016 tarihi itibariyle Türkiye Elektrik İletim Anonim Şirketi (TEİAŞ) verilerine göre RES kurulu gücü $4601 \mathrm{MW}$ (Lisanssız: $8 \mathrm{MW}$ ) olup, santral sayıs1 130'dur (Lisanssız: 14 adet). Türkiye geneli kurulu güç 74.0 GW olup, RES'ler \%6.2'lik bir paya sahiptir [5]. Şekil 2'de Türkiye'nin yıllara bağlı RES kurulu gücü ve RES'lerden elektrik üretimi gelişimi görülmektedir. 2015 y1l sonu itibariyle işletmede olan santrallerin bölgelere göre dağılımı ise Şekil 3 'te görülmektedir. Bunların içinde ilk beş il ise sırasıyla Balıkesir, İzmir, Manisa, Hatay ve Aydın'dır [5, 10].

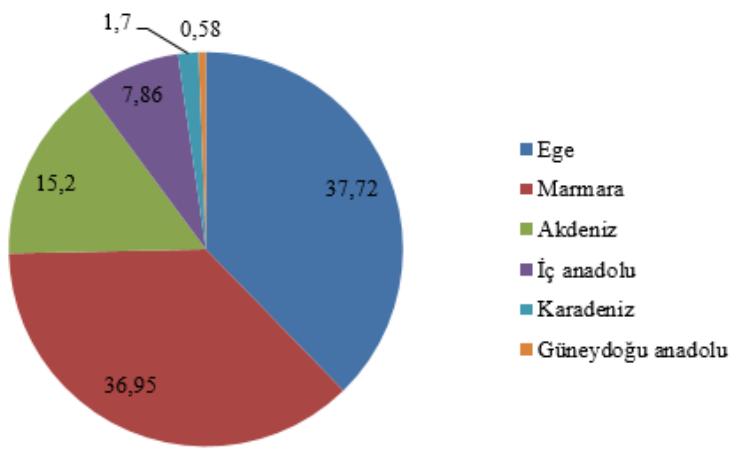

Şekil 3. İşletmede olan RES'lerin kurulu güç bakımından bölgelere göre dağılımı (\%) (RESs under operation by the regions in terms of installed power)

Elektrik İşleri Etüt İdaresi, 2006 yılında Türkiye'deki rüzgâr enerjisi potansiyelini göstermek için rüzgâr
Elektrik İşleri Etüt İdaresi, 2006 yılında Türkiye'deki rüzgâr enerjisi potansiyelini göstermek için rüzgâr enerjisi potansiyel atlasını (REPA) hazırlamıştır. REPA, orta-ölçekli sayısal hava tahmin modeli ve mikro-ölçekli rüzgâr akış modeli kullanılarak üretilen rüzgâr kaynak bilgilerini içermektedir. REPA'ya göre $50 \mathrm{~m}$ yükseklikteki yerler ve $7 \mathrm{~m} / \mathrm{s}$ ve üzeri hızlar düşünüldüğünde $48 \mathrm{GW}$ 'lık (kara üstü:38 GW, deniz üstü:10 GW) bir rüzgâr enerjisi elektrik kapasite potansiyeli bulunmaktadır. Şekil 4'te REPA görülmektedir [11].

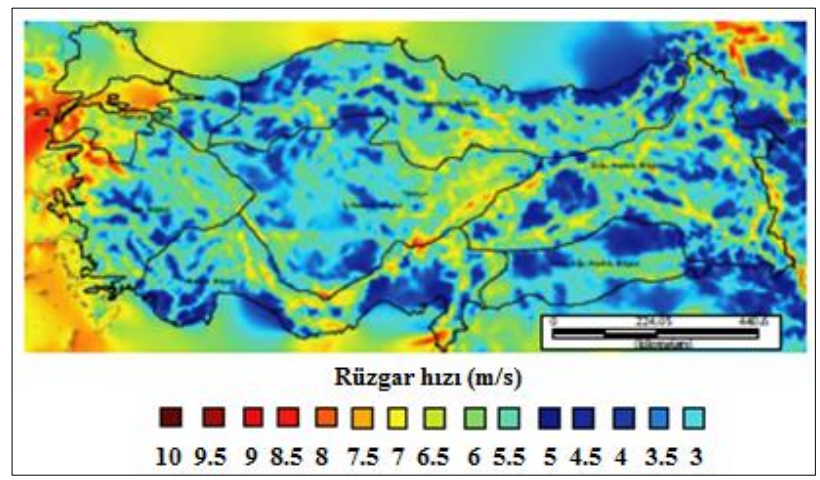

Şekil 4. REPA $50 \mathrm{~m}$ yükseklikte (REPA at $50 \mathrm{~m}$ height)

RES yatırımı yapılırken enerji potansiyelinin değerlendirilmesi önemli bir yere sahiptir. Bu anlamda, REPA yatırımcılara santral kurulacak yerin rüzgâr enerjisi potansiyeli hakkında bir fikir vermektedir. REPA'ya göre Türkiye üzerinde Ege ve Marmara bölgelerinde nispeten daha yüksek bir rüzgâr enerjisi potansiyeli bulunduğu görülmektedir. Şekil 3'e göre de halihazırda kurulu RES'lerin bu bölgelerde yoğunlaştıkları görülmektedir. REPA'dan noktasal rüzgâr kaynak bilgisi temin edilebilmektedir. İlgili

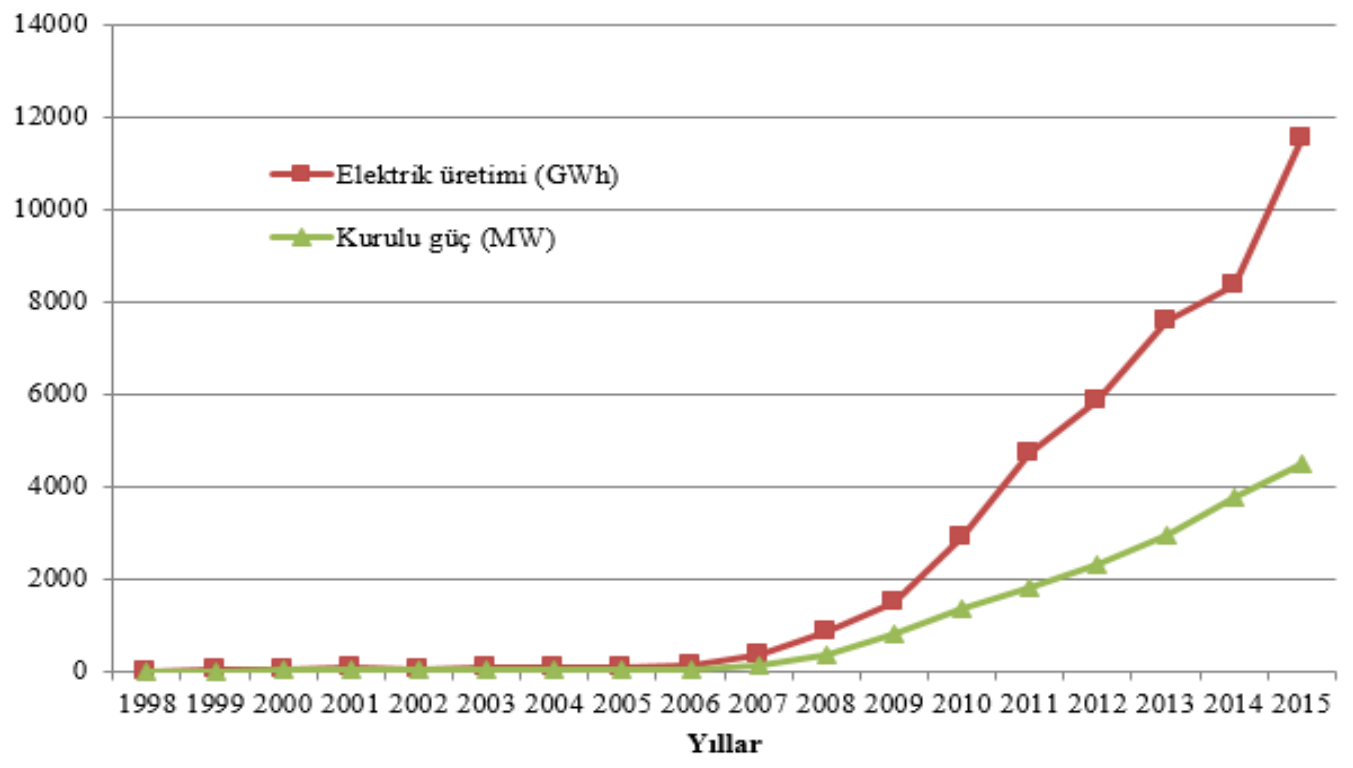

Șekil 2. Yıllara göre toplam rüzgâr enerjisi kurulu güç ve elektrik üretimi (Total wind energy installed capacity and electricity generation by the years) 
yönetmelikler ise lisans başvurusu yapmadan önce sahada rüzgâr ölçümü yapılmasını zorunlu kılmıştır.

\section{RÜZGÂR ENERJISİ TAHMINININ ÖNEMI (THE IMPORTANCE OF WIND ENERGY FORECAST)}

Rüzgâr enerjisi tahmini yakın gelecekte bir veya daha fazla rüzgâr türbininden beklenen elektrik üretimini ifade eder. Üretim olarak anılan değer genellikle bir RES için mümkün olabilecek güç anlamına da gelmektedir. Yani, güç üretimi her bir zaman aralığı için enerji olarak da ifade edilebilir. Rüzgâr enerjisi tahminleri elektrik iletim ve dağııım şirketleri, RES sahipleri ve enerji ticareti ile uğraşanlar tarafindan kullanılabilmektedir. Rüzgâr enerjisi tahminlerinin yapılmasıly:

- Güç sisteminin planlanmas1

- Rüzgâr salınımlarını kompanze etmek için rezerv planlama

- Yedek tutma miktarını planlama

- Bakım ve onarımları planlama

- Koruyucu bakım yapma

- Elektrik piyasasina teklif verme

- Yüksek fiyattan satış yaparak daha düşük ortalama rüzgârlı alanlarında değerlendirilmesine imkân tanıma

- Rüzgâr enerjisinin sistemdeki oranını artırma gibi faydalar sağlanır [13]. Rüzgâr enerjisi üretiminin tahmini ise tasarlanan uygulamaya bağlı olarak farklı zaman ölçeklerinde düşünülebilir:

- Milisaniyelerden birkaç dakikaya kadar olan tahminler türbinlerin aktif kontrolü için kullanılabilir. $\mathrm{Bu}$ tip tahminler genelde anlı tahminler olarak adlandırılmaktadır.

- Çok kısa süreli tahminler, 0-6 saat arası için yapılıp güç sisteminin yönetimi ve ticaret için kullanılan tahminlerdir [12].

- Takip eden 48-72 saatler arasındaki tahminler ise güç sisteminin yönetimi veya enerji ticareti için gerekli olmaktadır. Bunlar, geleneksel elektrik santralleri kullanımına (ünite taahhüdü) karar vermek ve bu santrallerin planlanmasinın optimize edilmesine yardımcı olabilmektedirler (en düşük maliyetle yükü karşılama). Ticaret uygulaması ile ilgili olarak, teklifler genellikle $d$. günün sabahında, $(d+1)$. günü için 00:00-23:59 saatleri aralığına kadar gereklidir. Bu tahminler kısa süreli tahminler olarak adlandırılır.

- Daha uzun zaman ölçekleri için (orta süreli tahmin, yaklaşık 5-7 gün ilerisine kadar) tahminler, rüzgâr santralleri, geleneksel elektrik üretim santralleri veya iletim hatlarının bakımlarının planlamasını yapmak için düşünülmektedir. Büyük rüzgâr santralleri veya deniz üstü santralların plansız bakımları cezai durum ortaya çıkarabileceğinden bakımlarının planlanması özel bir öneme sahip olabilir [13].
Modern rüzgâr tahmini sistemleri birkaç günlük zaman dilimi içinde rüzgâr tahmini sağlamak için sayısal hava tahmini (SHT) kullanır. Bu nedenle, geleceğe ait tüm bilgiler özellikle rüzgâr alanındaki beklenen gelişmeler SHT ile sağlanır. Ulusal meteoroloji servisleri ve aynı zamanda özel hava verisi sağlayıcı şirketler rüzgâr tahmini için uygun olan farklı SHT verileri sunarlar. Rüzgâr tahmininde anahtar konu verilen SHT verilerini bir rüzgâr türbininin çıktısına dönüştürmektir. Bu amaçla son yıllarda iki farklı temel yaklaşım geliştirilmiş̧ir; istatistiksel yaklaşım ve fiziksel yaklaşım. İkisi de rüzgâr tahmini sistemlerinin bilimsel olarak ve aynı zamanda ticari olarak başarılı olmasına öncülük etmiştir [13].

Yukarıda bahsedilen muhtemel faydalar çerçevesinde 2010 y1lında T.C. ETKB Yenilenebilir Enerji Genel Müdürlüğü, TÜBİTAK ve Meteoroloji Genel Müdürlüğü (MGM) işbirliğinde Milli tabanlı Rüzgâr Gücü İzleme ve Tahmin Merkezi (RITTM) projesine başlanmıştır. Bu projenin amac1, Türkiye'deki tüm RES'lerin tek bir merkezden izlenmesi ve oluşturulan rüzgâr enerjisi tahminlerinin piyasa katılımcıları ve sistem işletmecisiyle paylaşılmasıdır. Böylelikle rüzgâr gücü tahmini, sistem işletmecisinin ve piyasa katılımcısının gün öncesi planlamasını daha sağlıklı yapmasına imkân tanıyacaktır [12]. Türkiye'de rüzgâr kaynağından büyük ölçekli elektrik enerjisi üretiminin gerçekleştirilebilmesi ve rüzgâr santrallerinin elektrik sistemine entegrasyonu için gerekli önlemlerin alınmasında faydalı olabilecek projede 0-48 saat (kısa süreli), 0-6 saat (çok kısa süreli) ve olasiliksal tahminler ( $\% 50$ ve $\% 90$ ihtimal ile) üretilmektedir. Tasarlanan tahmin algoritmasında fiziksel ve istatistiksel yöntemler kombine edilmektedir. İstatistiksel yaklaşımda öğrenme yöntemleri olarak doğrusal regresyon, destek vektör makineleri ve yapay sinir ağları kullanılmaktadır. Fiziksel yaklaşım için ise santral sahaları hesaplamalı akışkanlar dinamiği yazılımı ile modellenmektedir. Proje kapsamında ilgili tahmin algoritmasına MGM hava tahmini, Avrupa Orta Ölçekli hava tahmini, Küresel Tahmin Sistemi ve RES güç verileri girdi olarak kullanılmaktadır. Şekil 5'te RITM genel mimarisi gösterilmektedir [14].

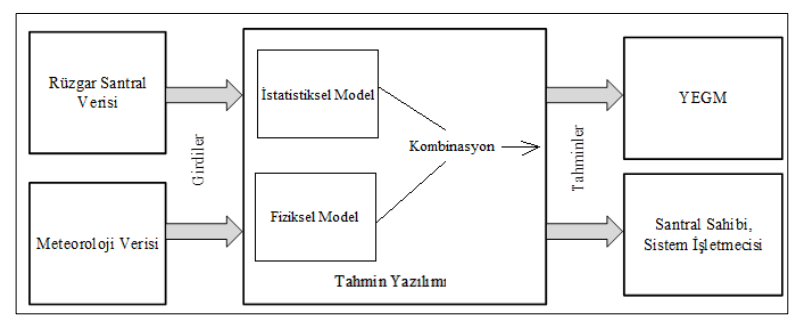

Şekil 5. RITTM genel yapısı (RITTM general structure)

RITTM projesinde izlenebilen rüzgâr kurulu gücü 06.05.2016 tarihi itibariyle 4385 MW olup, ilgili tarihteki Türkiye rüzgâr kurulu gücünün \%95'ine tekabül etmektedir [12]. Rüzgâr enerjisi tahminleri hata oranları aşağıdaki şekilde hesaplanmaktadır: 


$$
\operatorname{NMAE}(\%)=\left|\frac{E_{T}-E_{\ddot{U}}}{K . G \ddot{U} C ̧}\right| \cdot 100
$$

Burada NMAE, $E_{T}, E_{\ddot{U}}$ ve $K . G \ddot{U} C ̧$ ifadeleri sırasıyla normalize edilmiş mutlak hatayı, saatlik elektrik üretim tahmini değeri, gerçek zamanda saatlik elektrik üretim değerini ve santralin elektrik kurulu güç değerini ifade eder [14].

\section{TÜRKIYY ELEKTRIK PIYASA YAPISI (TURKISH ELECTRICITY MARKET STRUCTURE)}

Türkiye için organize toptan elektrik piyasaları, elektrik enerjisi, kapasitesi veya perakende alış satışının gerçekleştirildiği ve piyasa işletim lisansına sahip merkezî bir aracı tüzel kişilik tarafından organize edilip işletilen GÖP, gün içi piyasa (GIP) ile sermaye piyasası aracı niteliğindeki standardize edilmiş elektrik sözleşmelerinin ve dayanağı elektrik enerjisi ve/veya kapasitesi olan türev ürünlerin işlem gördüğü ve Borsa İstanbul Anonim Şirketi tarafından işletilen piyasaları ve TEİAŞ tarafından organize edilip işletilen dengeleme güç piyasası (DGP) ve yan hizmetler piyasası (YHP) gibi elektrik piyasalarını ifade eder [15]. Şekil 6, Türkiye elektrik piyasasındaki genel akışı göstermektedir [16].

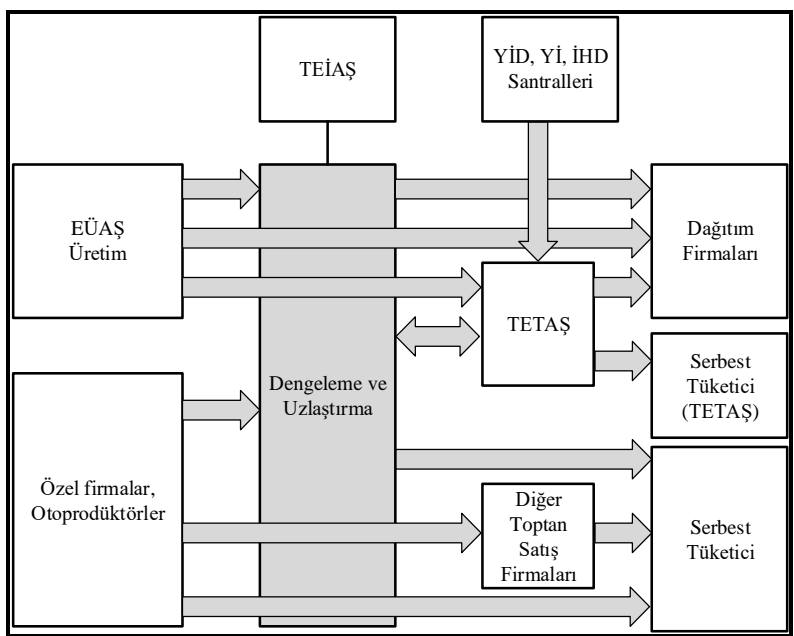

Şekil 2. Türkiye organize toptan elektrik enerjisi piyasas (Turkey's organized whole sale electricity market)

İkili anlaşmalar neticesinde piyasada oluşan boşlukları doldurmak ve sistem dengesizliğini gidermek için oluşturulan sanal piyasa "Dengeleme ve Uzlaştırma" piyasası ve bu piyasa kurallarını açıklayan yönetmelik "Dengeleme ve Uzlaştırma Yönetmeliğgi" olarak adlandırılmaktadır. Tanım olarak "dengeleme", toplam arzı toplam talebe eşit olacak şekilde ayarlama ve sistemi dengede tutma işlemidir. Dengeleme mekanizması, ikili anlaşmaları tamamlayıcı nitelikte olup, gün öncesi dengeleme, gün içi dengeleme ile gerçek zamanlı dengelemeden oluşan faaliyetleri kapsar [15].

Türkiye'de yürütülen dengeleme ve elektrik enerjisi arz ve talebinin gerçek zamanlı olarak dengelenmesinden sorumlu kuruluş TEİAŞ'ın bir birimi olan Milli yük tevzi merkezi (MYTM)'dir. Diğer bir deyişle, sistem işletmecisi MYTM'dir. "Elektrik Şebeke Yönetmeliği"ne göre sistemin $50 \mathrm{~Hz}$ olan nominal frekansı, TEİAŞ tarafından $49.8-50.2 \mathrm{~Hz}$ aralığında kontrol edilir. MYTM, özellikleri yönetmelikle belirlenmiş her tür üretim ve tüketim tesisini izler, gerektiğinde dengelemenin sağlanabilmesi ve toplam talebin karşılanabilmesi için üretim tesislerine yük artırımı veya azaltımı yönünde talimat verir.

Türkiye'de mevcut elektrik piyasası mevzuatına göre RES'ler Yap-işlet-devret modeli, lisanslı (Enerji Piyasası Düzenleme Kurumu-EPDK iznine tabii) ve lisanssiz şekillerinde faaliyet göstermektedirler. Türkiye elektrik enerjisi sektöründe yenilenebilir enerji santralleri ürettikleri elektriği:

- İkili anlaşma ile tedarik şirketleri, TETAŞ ya da serbest tüketicilere,

- GÖP ve GİP kapsamında EPİAŞ'a,

- YEKDEM kapsamında EPİAŞ'a

satabilme imkânına sahiptirler. Şekil 7'de gösterildiği gibi bir RES tarafından üretilen elektrik enerjisi ikili anlaşma, GÖP ve GIP mekanizmasında değerlendirebilir.

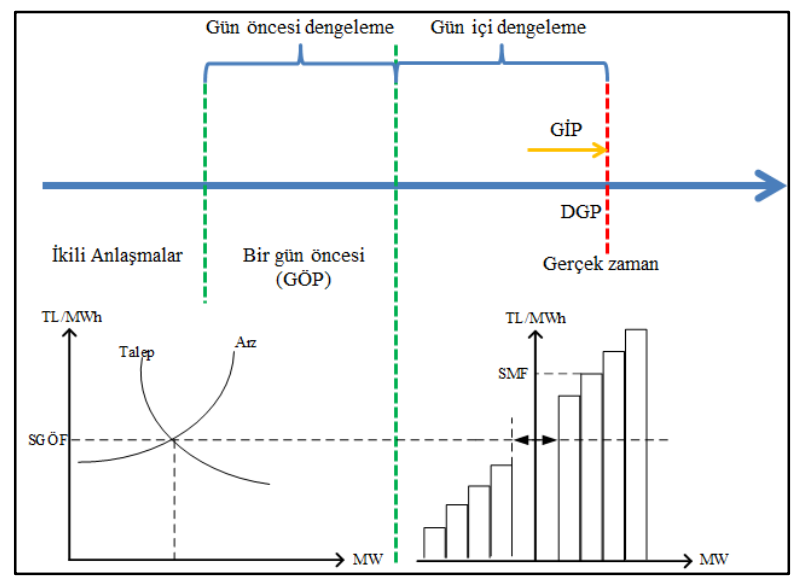

Şekil 7. Dengeleme faaliyetleri ve fiyatların oluşumu (Balancing activities and price realizing)

Bir RES YEKDEM'de faaliyet gösterdiği takdirde ise rüzgâr türbininde kullanılan yerli ürün oranlarına bağlı olarak 7.3 ilâ 11.0 USD-cent/kWh arasında sabit destekleme fiyatlarından yararlanabilmektedir [1]. YEKDEM takvim yılı bazında işletilip, YEKDEM'e bir takvim yılı için tabi olan üretim lisansı sahipleri, uygulamaya dahil oldukları takvim yılı içerisinde YEKDEM'den çıkamazlar. Yani, YEKDEM'e başvurusu kabul edilen üretim tesisi, ikili anlaşma veya piyasaya satış şeklinde kullanılamaz ve enerji üretimi nedeniyle de dengesizliğe düşmez [17]. Şekil 8 yıllık ortalama düzeyde GÖP [18] ve YEKDEM için karşılaştırmalı fiyat seviyelerini (7.3 USD-cent/kWh ve 11.0 USD-cent/kWh için) göstermektedir. 


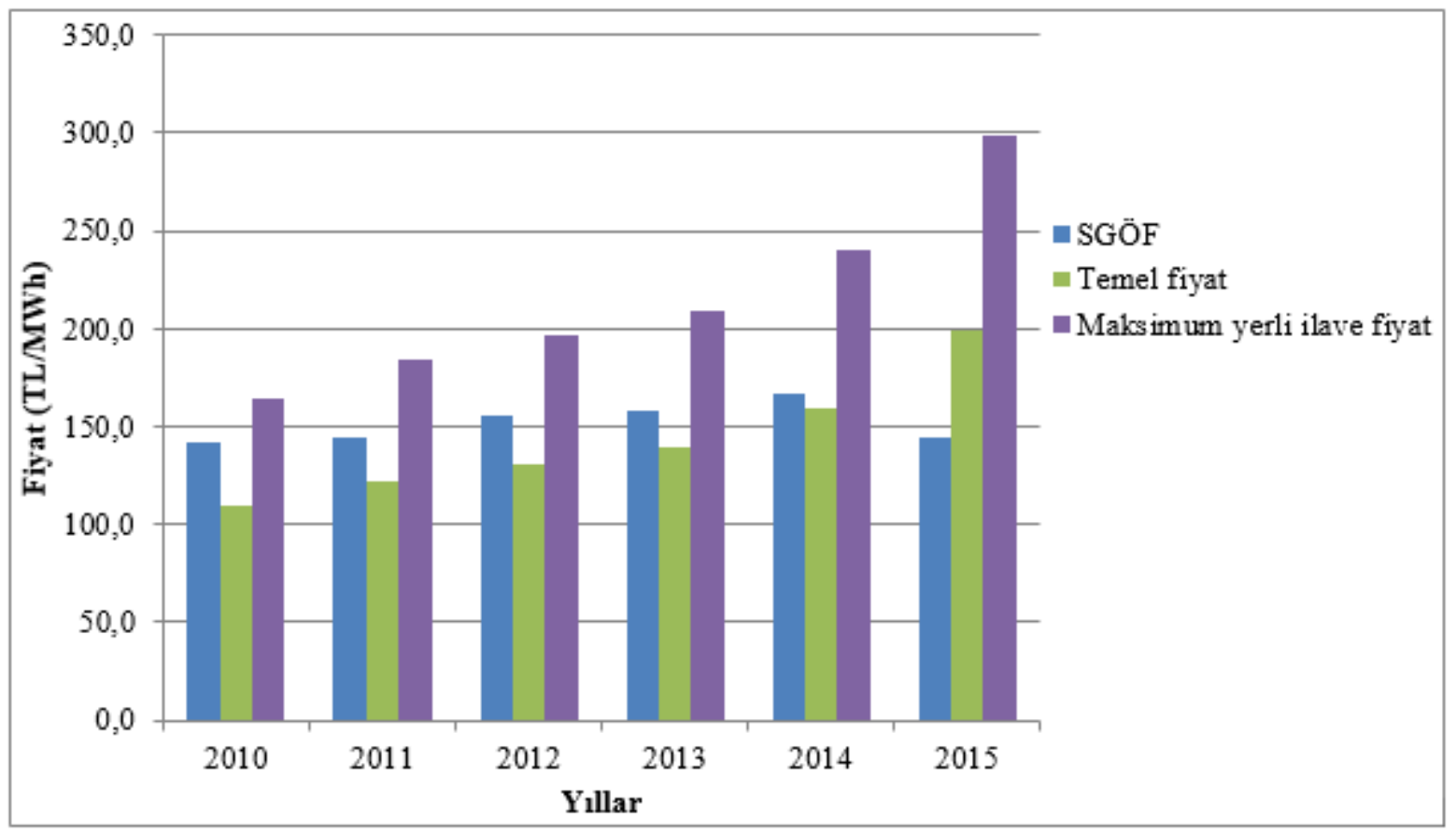

Şekil 8. Yıllara göre ortalama SGÖF ve YEKDEM fiyatları (Average SGÖF and YEKDEM prices by the years)

Piyasa katılımcılarının üretimi, tüketimi ve teklif edilen enerji miktarı arasında sapmalar oluşursa çift fiyatlandırma mekanizmasına göre düştükleri dengesizlik cezalandırılır. $\mathrm{Bu}$ işlemin amacı elektrik sisteminin dengede tutulmasını sağlamak içindir. Çift fiyatlandırma mekanizması 2011 yılından sonra devreye girmiştir. Aşağıdaki denklemler sırasıyla elektrik piyasasında faaliyet gösteren bir enerji santralinin enerji dengesizlik tutarını (EDT), GÖP'te faaliyet gösterdiğinde elde ettiği geliri $\left(G_{G O ̈ P}\right)$ ve YEKDEM'de faaliyet gösterdiğinde elde ettiği geliri ( $\left.G_{Y E K D E M}\right)$ göstermektedir $[15,17]$ :

$E D T=E D M(-) \cdot \operatorname{mak}(S G O ̈ F, S M F) \cdot(1+k)+E D M(+) \cdot \min (S G O ̈ F, S M F) \cdot(1-l)$

$G_{G \ddot{P}}=E_{T} \cdot S G \ddot{O} F+E D T$

$$
G_{\text {YEKDEM }}=E_{\ddot{U}} \cdot K U R . Y E K F
$$

Burada $E D M(-), E D M(+), S G O ̈ F, S M F, K U R, Y E K F, k$ ve $l$ ifadeleri sırasıyla negatif veya pozitif yönde enerji dengesizlik miktarını, sistem gün öncesi fiyatını, sistem marjinal fiyatını, ABD doları seviyesini, yenilenebilir enerji destekleme fiyatını ve EPDK tarafından belirlenen katsayıları ifade eder. Buradan görüldügü $\mathrm{MWh}$ başına $G_{Y E K D E M}$ seviyesi tamamen kur seviyesine bağlıdır.

\section{ELEKTRIK PIYASASI UYGULAMASI (ELECTRICITY MARKET APPLICATION)}

$\mathrm{Bu}$ bölümde, rüzgâr enerjisi tahminlerinin önemini göstermek üzere RES'lerin rüzgâr enerjisi tahminlerine dayalı olarak GÖP'te ve YEKDEM'de kazançlarının analiz edilmesi amaçlanmıştır. Bunun için RİTM projesinden alınan 01.01.2013-31.12.2013 tarihleri aras1 verilere göre Türkiye'deki 14 RES için önceki bölümlerde bahsedilen ilgili mevzuat çerçevesindeki eşitlikler kullanılarak rüzgâr enerjisi tahminlerine dayalı elektrik piyasası uygulaması gerçekleştirilmiştir. Analizler gerçekleştirilirken piyasa durumunun (piyasa fiyatları) sabit kaldığı varsayılmıştır. Şekil 9'daki haritada çalışılan santrallerin Türkiye haritası üzerindeki mevkileri görülmektedir. Çalışmada RES'lerin yoğun olarak bulunduğu bölgeler seçilmiştir.

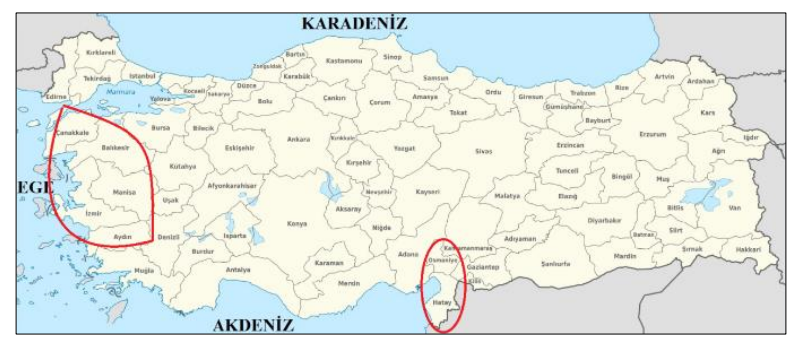

Şekil 9. Çalış1lan RES'lere ait bölgeler (The regions of the studied RESs)

RİTM sisteminde GÖP'te kullanılabilecek tahminler ilgili RES'lere her gün 07:45-10:00 saatleri arasında sağlanmaktadır. RES'ler tarafından GÖP'te kullanılmak üzere üretim tahmin ve fiyat teklifleri her gün saat 11:30'a kadar piyasa işletmecisine bildirilmelidir. YEKDEM'e katılacak RES'ler saatlik enerji üretim tahminlerini her bir gün için, önceki gün saat 09:00 itibariyle sistem işletmecisi tarafından belirlenecek şekle (fiyattan bağımsız teklif) uygun olarak sistem işletmecisine bildirir. Sürekli devam eden bir piyasa olan GİP kullanıldığı takdirde ise son teklif zamanı elektriğin fiziksel teslimatının iki saat öncesidir. $\mathrm{Bu}$ piyasa için verilen teklifler güncellenebilir, iptal edilebilir veya pasif yapılabilir. DGP, sistem 
işletmecisine gerçek zamanlı dengeleme için en fazla 15 dakika içinde devreye girebilecek yedek kapasiteyi sağlamakta idi. Bağımsız olarak 15 dakika içerisinde asgari 10 MW yük alabilen veya yük atabilen dengeleme birimleri DGP'ye katılmakla yükümlü olup, RES'ler bu sorumluluktan muaftırlar. Bu piyasa, esas olarak ticaret için değil sistemin gerçek zamanda dengede tutulması içindir. Burada ticaret yapmak oldukça risklidir ve ticaret yapılması gereken yer GÖP ve GİP'tir.

Analizlere ilk olarak RES'lerin üretim profilinin anlaşılması amacıyla RİTM kullanıcı yazılımlarından alınan grafiğin incelenmesiyle başlanmıştır. Şekil 10'da 20.11.2015-24.12.2015 tarih aralığında RİTM projesinden alınan Türkiye genelinde RITM'e bağlı tüm RES'ler için örnek bir elektrik gücü değişim profili grafiği gösterilmektedir. Grafikteki iniş çıkışlardan görüldüğü gibi rüzgârın değişken yapısına bağlı durumdan kaynaklı gerçek zamanda oluşabilecek dengesizlikler sistem işletmecisi tarafindan verilen talimatlar (yük alma-atma) doğrultusunda diğer elektrik üretim santralleri (dengeleme birimleri) tarafindan dengelenmektedir.

Seçilen 14 adet RES'in her birinde GÖP-YEKDEM piyasa geliri uygulaması gerçekleştirilmiş olup, grafikler Şekil 11(a) ilâ Şekil 11(g)'de aşağıda gösterilmiştir. Bu grafiklerdeki tüm değerler yıllık ortalamalar olmak üzere; Göp-Min, ilgili RES'in GÖP'te hâlihazırdaki tahmin hatası (\%NMAE) ile elde ettiği geliri; Göp-Mak $\% 0$ tahmin hatası ile teorik olarak ulaşılabilecek en fazla GÖP gelirini; Göp-Ort ise Göp-Min ve Göp-Mak'ın ortalamasını ifade etmektedir. Yekdem-Min, YekdemMak ve Yekdem-Ort ise sırasıyla kWh başına 7.3 USDcent, 11.0 USD-cent ve bu ikisinin ortalaması kullanılarak piyasada oluşan destek fiyatlarını göstermektedir. Grafiklerden görüldüğü üzere santrallerin hâlihazırdaki tahmin hataları ile GÖP'te Yekdem-Min fiyatlarından daha avantajlı konumda oldukları görülmektedir.

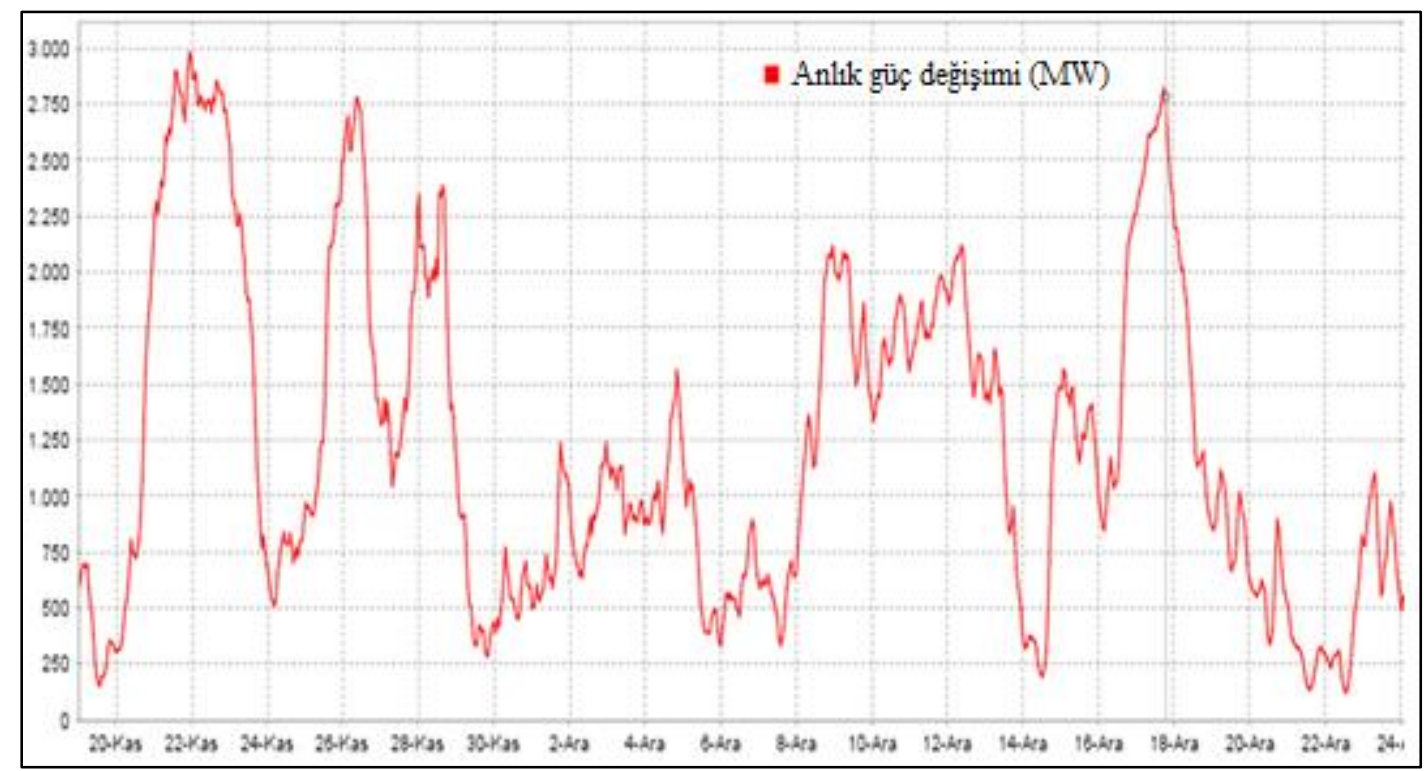

Şekil 10. RES'lerde gerçekleşen örnek bir elektrik üretim profili (Example electricity production profile in the RESs)

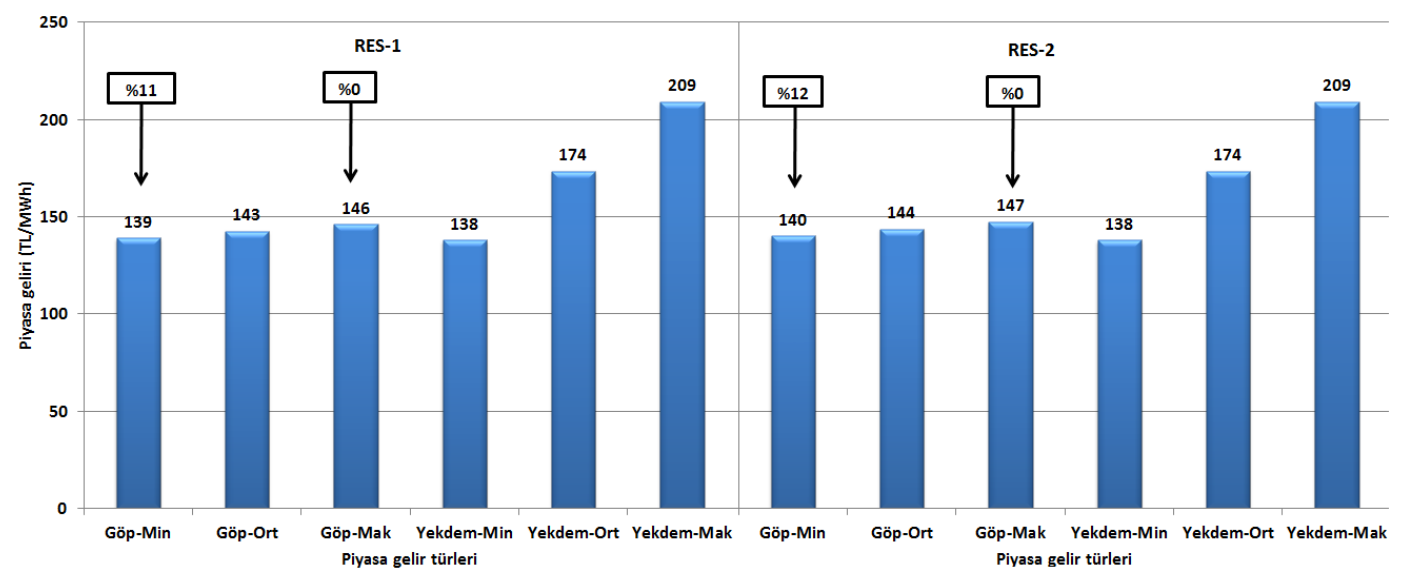

Şekil 11(a). Piyasa gelir düzeyleri (Market revenue level) 


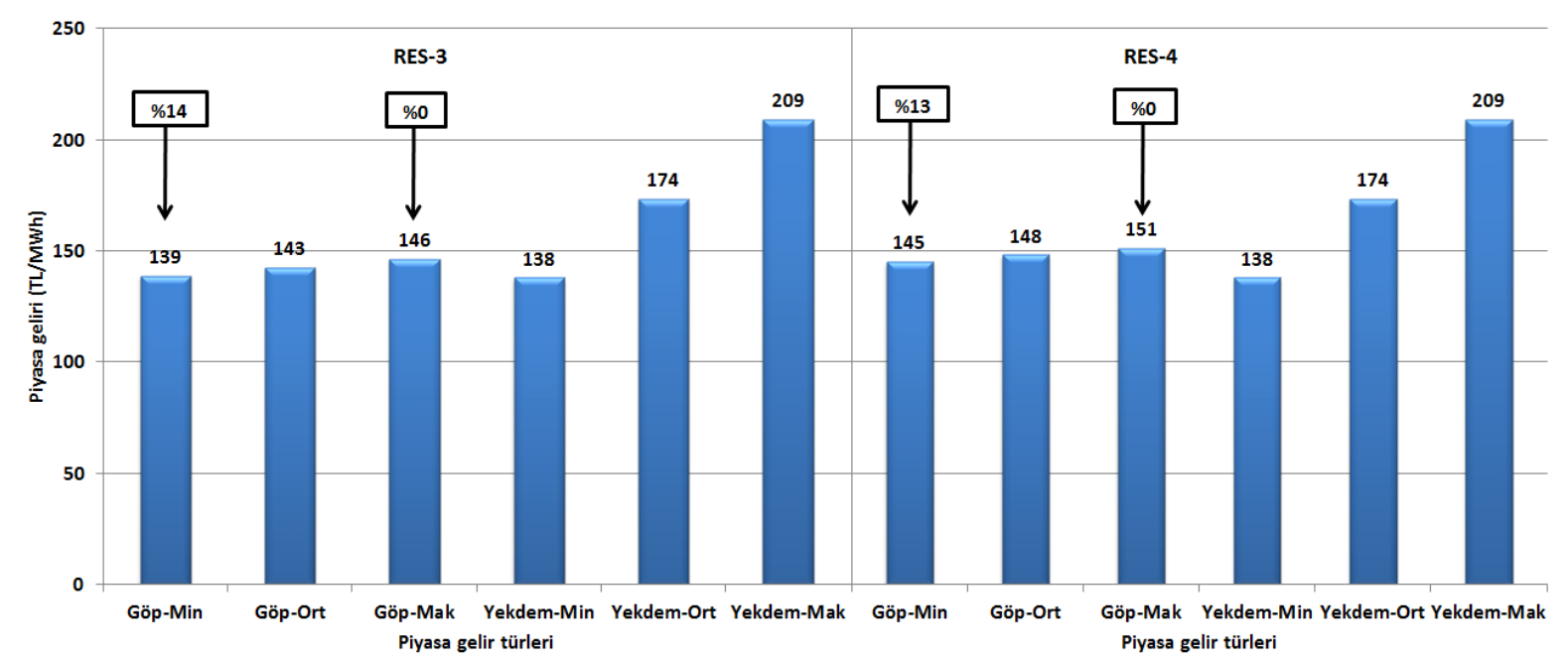

Şekil 11(b). Piyasa gelir düzeyleri (Market revenue level)

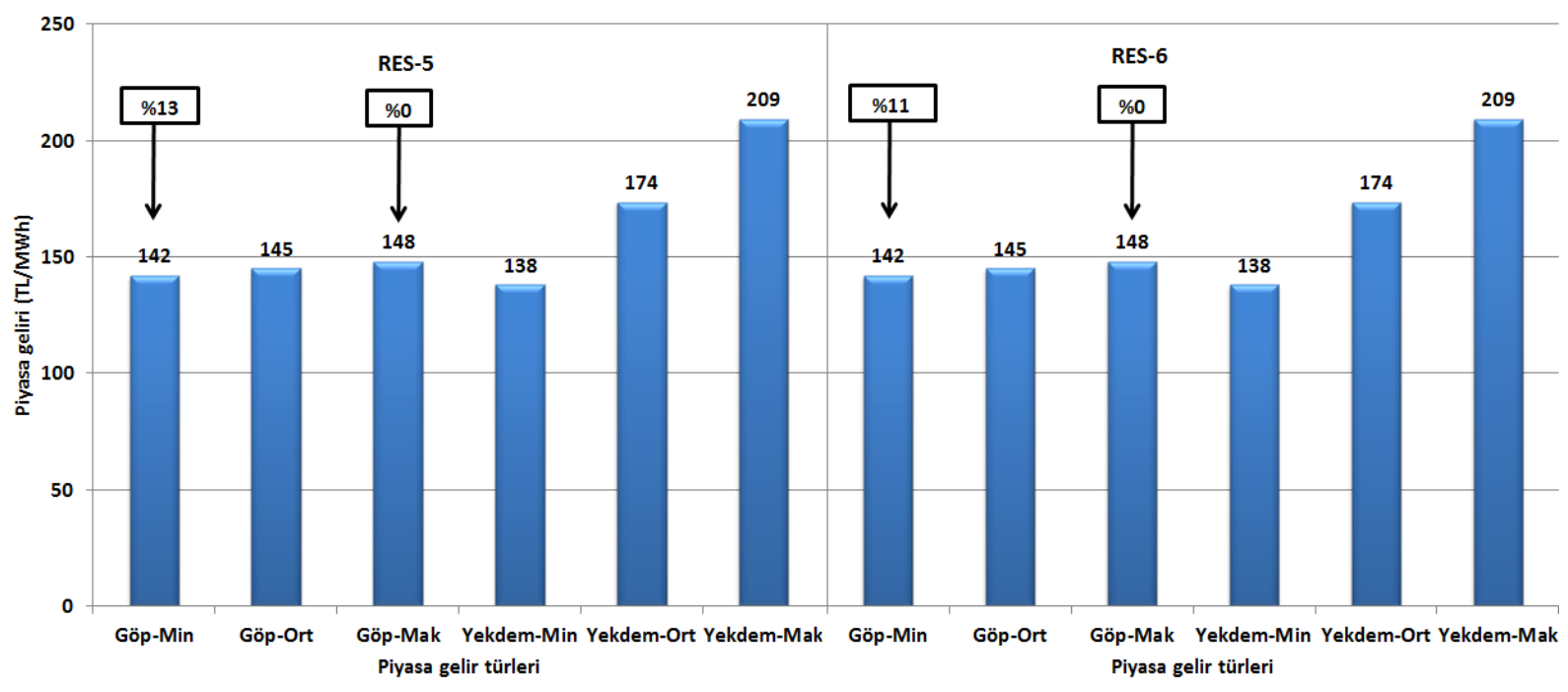

Şekil 11(c). Piyasa gelir düzeyleri (Market revenue level)

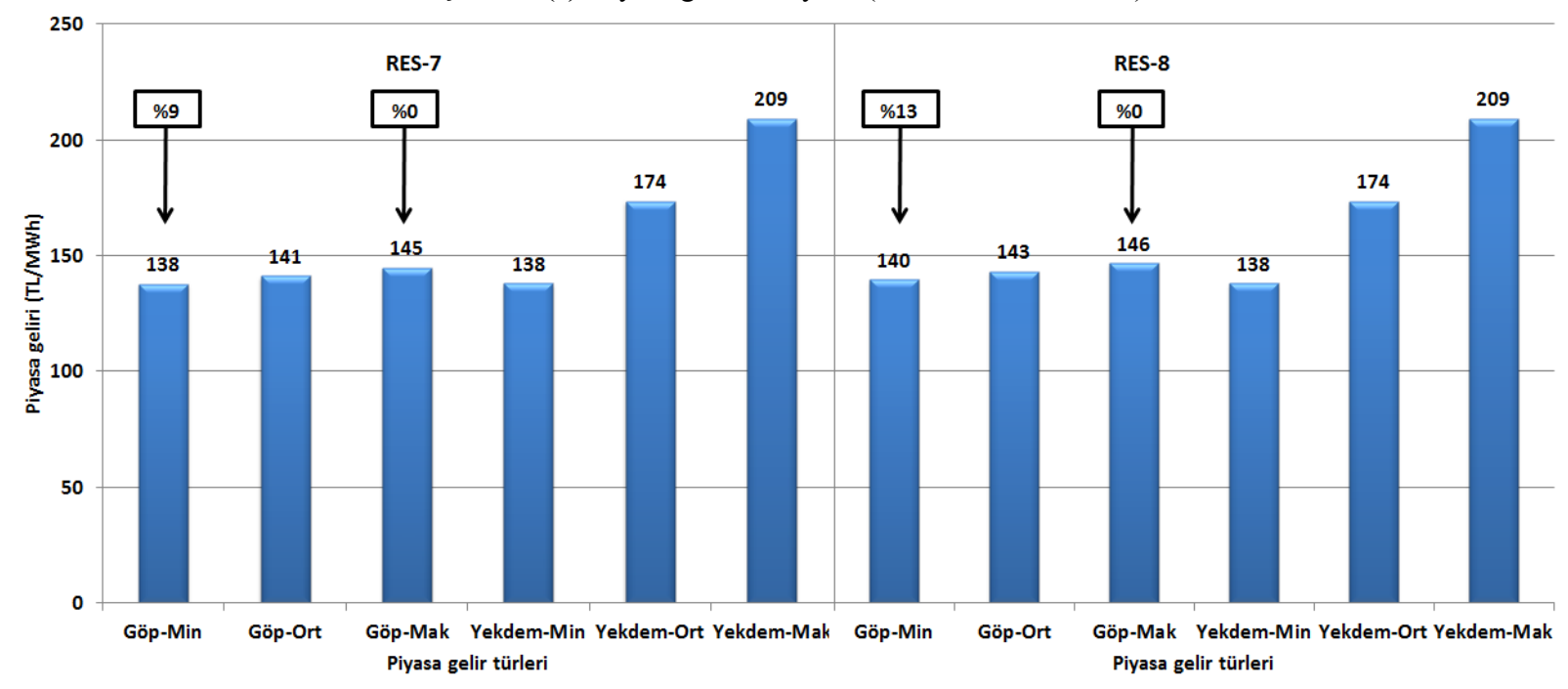

Şekil 11(d). Piyasa gelir düzeyleri (Market revenue level) 


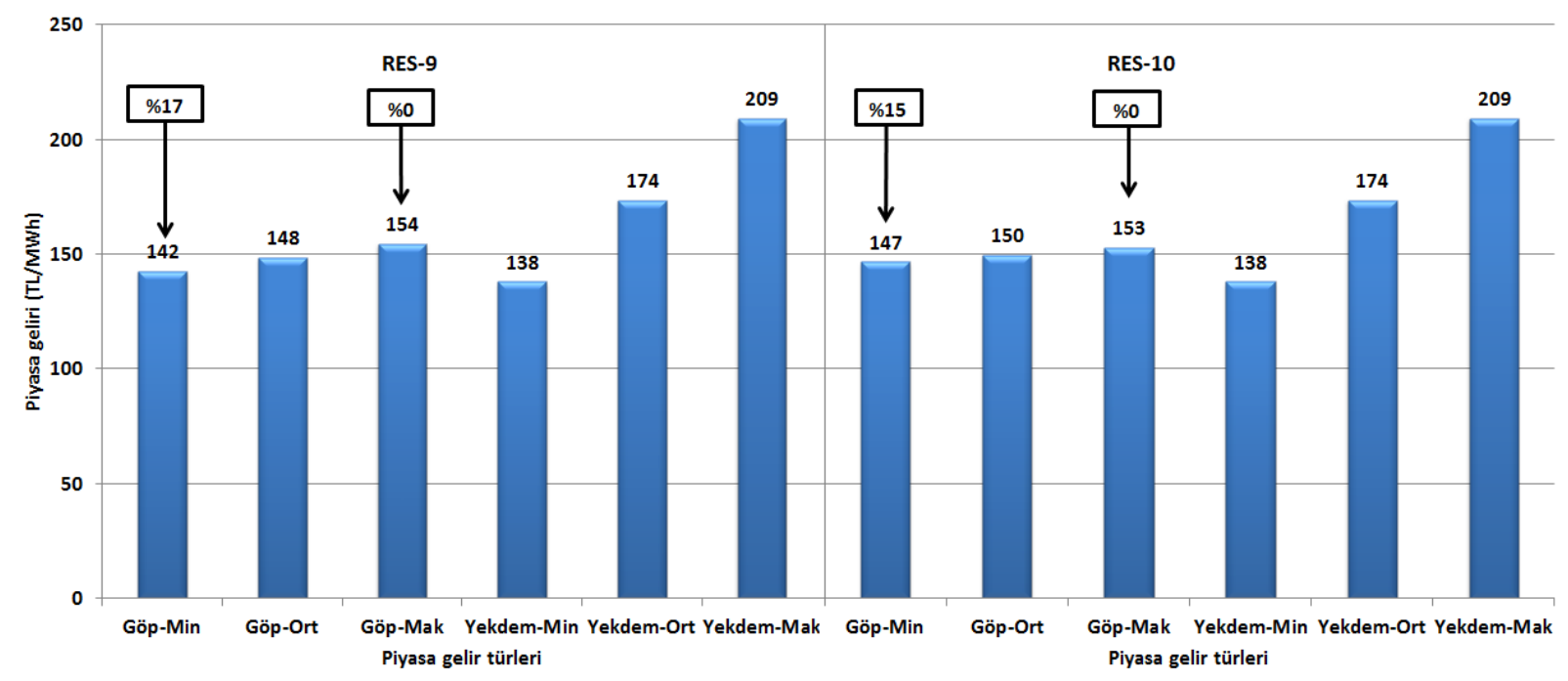

Şekil 11(e). Piyasa gelir düzeyleri (Market revenue level)

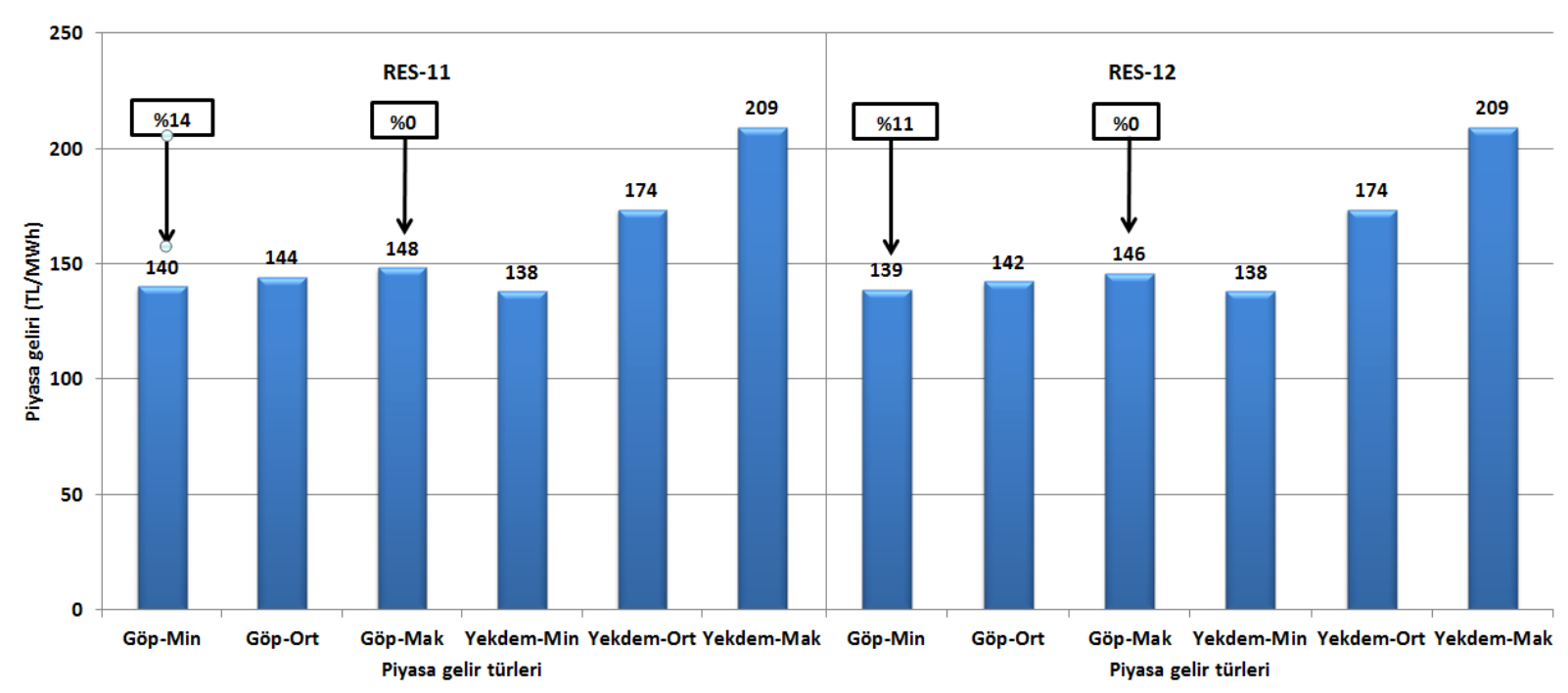

Şekil 11(f). Piyasa gelir düzeyleri (Market revenue level)

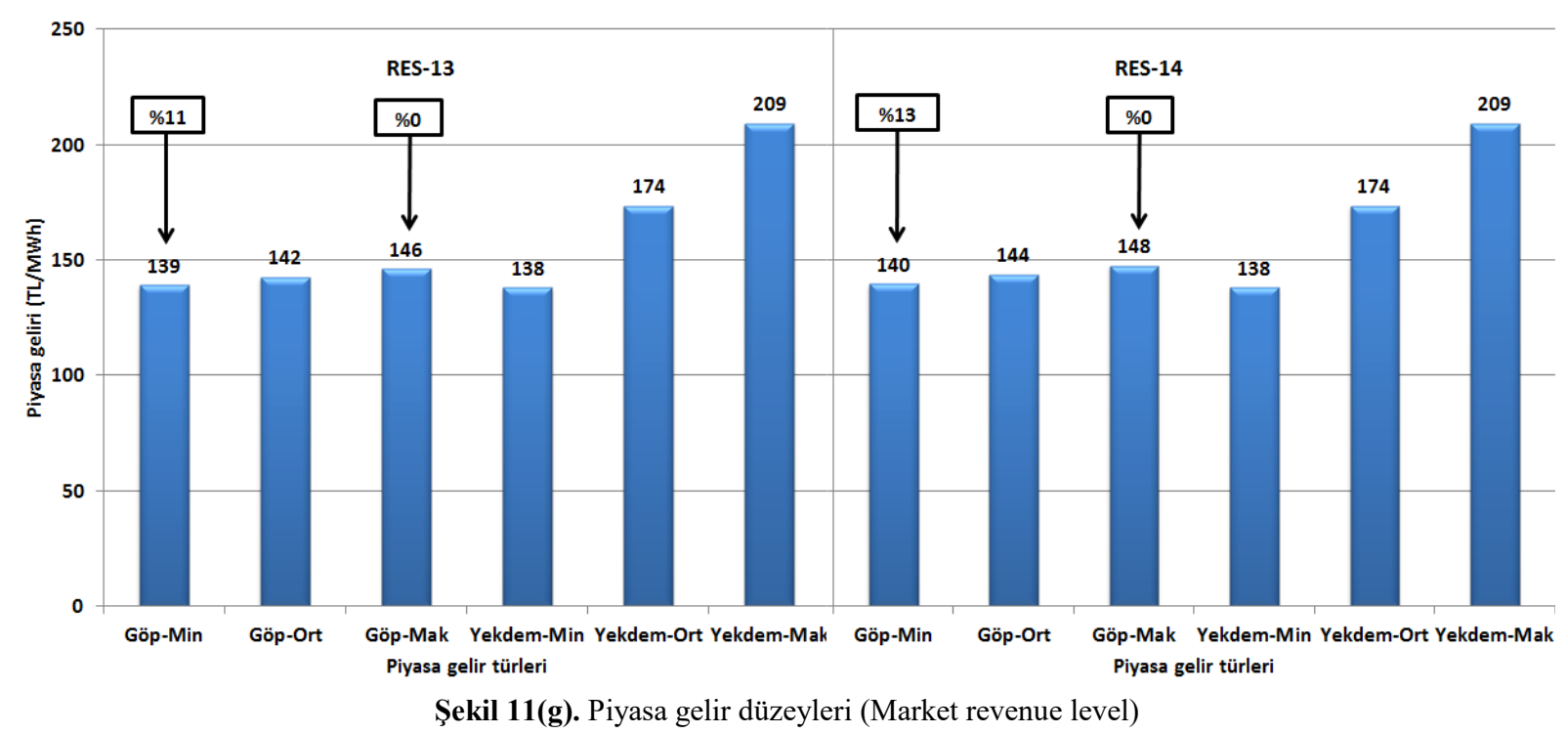


Santrallerin hâlihazırda elde ettikleri gelirlerini, tahmin hatalarını azaltarak ve/veya GİP'i etkin kullanarak GöpOrt düzeylerine çekebilme imkânları bulunmaktadır. Ancak, tüm santrallerin bu grafiklere göre yerli aksam kullanarak YEKDEM'e katılmaları halinde (YekdemOrt veya Yekdem-Mak ile) hem piyasa risklerinden korunacağı hem de GÖP fiyatına göre daha avantajlı duruma geleceği açıkça görülmektedir.

\section{SONUÇLAR (CONLUSIONS)}

Son y1llarda ilgi gören temiz enerji, enerji güvenliği ve çeşitliliği konularına paralel olarak yenilenebilir enerji kaynakları ile elektrik üretimi yapan santrallerin sayısı bütün dünyada önemli ölçüde artmaktadır. Özellikle rüzgâr enerjisi yenilenebilir enerji kaynakları arasında oldukça fazla ilgi görmektedir ve kurulu gücü diğer yenilenebilir enerji kaynaklarına göre daha çok artmaktadir.

Rüzgâr enerjisinden elektrik üretimi oldukça değişken bir profile sahiptir. Sağlıklı bir elektrik piyasası işletimi için üretilen elektrik enerjisinin tahmini büyük önem arz etmektedir. Rüzgâr enerjisinden elektrik üretimini tahmin hata payı; tahmin dönemi kısaldıkça azalmasına karşın bu konuda hâlen fosil kaynak kullanan santrallere göre kötüdür. $\mathrm{Bu}$ kaynağın güvenilir, ekonomik ve kaliteli bir biçimde işletilmesi açısından enerji tahmin modelleri büyük önem kazanmıştır. Bu anlamda, 2013 yılı değerleri kullanılarak Türkiye elektrik piyasası için GÖP-YEKDEM karşılaştırmalı olarak 14 adet RES ile tahmin etkileri için analizler gerçekleştirilmiştir. Yapılan çalışmalarda başlıca şu sonuçlara ulaşılmıştır:

Santraller açısından:

- Santrallerin tahmin hatalarını azaltarak GÖP'te elde ettikleri gelirleri arttırma imkânları bulunmaktadır.

- Santrallerin YEKDEM kapsamında yerli ilave fiyatlarından faydalandıkları takdirde gelirlerini arttırma ve GÖP risklerinden arınma imkânları bulunmaktadır.

- Özellikle RES'ler için faydalı olacağı düşünülen ve daha kısa süre için tahmin hatalarının daha düşük oluşabileceği piyasa ortamı olan GİP'in etkin kullanılması halinde santrallerin gelirlerini arttırma imkânı bulunmaktadır.

- Santrallerin doğru piyasa tercihi yapmaları ve belirtilen faydaları sağlamaları daha çok yatırım yapmalarına imkân sağlayabileceğinden Türkiye'nin kapasite hedeflerine ulaşmada yardımcı olacaktır.

Elektrik piyasası açısından:

- Sağlıklı bir GÖP planlaması yapılması,

- DGP kapsamında yük alma ve yük atma yönündeki talimatların azalması ve dolayısıyla elektrik piyasasında enerji dengesizliklerinin ve maliyetlerinin azalması,
- Sistem işletmecisine bakımlar, kısıt yönetimi, sıcak yedekler, rezerv yönetimi gibi konularda yardımcı olarak işletme maliyetlerinin azalması,

- Üretim portföyünde rüzgâr enerjisine ağırlık verilmesi ile fosil kaynakların daha az kullanılması,

- Şebekeye daha fazla yenilenebilir enerji kaynağ entegrasyonu sağlanması,

yönünde faydalar sağlanabilecektir. YEKDEM'e katılan tesislerin RES kurulu gücü 2011-2015 yıl periyodunda en fazla 2731 MW olurken, 2016 y1lı için bu değer 4319 MW'a ulaşmıştır [19]. EPDK'ya 2016 yılı için YEKDEM'e dahil olmak üzere başvuran tüm santrallerin kurulu gücünün 15000 MW'1 geçmesi ve ayrıca dengeleme birimlerinin de YEKDEM'e girmesi sonucu, elektrik piyasasındaki olumsuzlukları asgari düzeye indirmek için yeni düzenleme yapma çalışmalarına hız verilmiştir [20].

Bu makaledeki analizlerin yapıldığı tarihlerde YEKDEM kapsaminda bulunan ve sistem dengesizliklerinden muaf olan piyasa katılımcılarının dengelemeye katkıda bulunacağ 1 ve katkıda bulunduğu ölçüde daha fazla gelir elde edeceği bir mekanizma değişikliği üzerinde çalışılmaktaydı. Bu amaçla, 29 Nisan 2016 tarihinde yayınlanan yeni yönetmelik [21] ile piyasada üretim miktarlarını doğru tahmin ederek dengesizliklerini en aza indirecek olan üreticilerin daha fazla gelir elde etmesi ve karşılığında daha dengeli teklif setleri vermesi hedeflenmiştir. Yeni YEKDEM dizaynı ile üretimlerini GÖP, GIP'te ve ikili anlaşmalar ile uzun vadede enerjisini satabilen, daha fazla risk alan buna karşılık daha çok finansal kazanç elde edebilecek üretici portföylerinin oluşması beklenmektedir.

$\mathrm{Bu}$ çalışmada, genel anlamda RES'lerin enerji üretimlerine ve tahminlerine dayalı olarak elektrik piyasası ve fiyat etkileri araştırılmıştır. Her ne kadar RES'ler tarafindan 2015 ve 2016 yillarında 10 yıl ile sınırlı YEKDEM daha çok tercih edilmiş olsa bile, önemli bir başvuru teşkil eden GÖP ile karşılaştırmalı analizler güncelliğini kaybetmeyecek önemli bir konudur.

Sonuç olarak ülkemizde cari işlemler dengesinde büyük pay sahibi olan fosil yakıtlara bağımlılığın azaltılması için yenilenebilir enerji kaynakları arasında önemli bir yere sahip olan rüzgâr enerjisinin elektrik piyasasında doğru yönetilmesi gereklidir. Türkiye'nin elektrik talebinin artışı ve yüksek rüzgâr enerjisi potansiyeli düşünüldügünde bunun için ulusal tahmin sistemlerinin oluşturulması, yönetilmesi ve geliştirilmesi önemli bir yere sahiptir. $\mathrm{Bu}$ anlamda RITM projesi ve yeni YEKDEM yönetmeliği Türkiye için önemli bir başlangıçtır.

\section{TEŞEKKÜR (ACKNOWLEDGEMENT)}

$\mathrm{Bu}$ makaleye sağladıkları katkılardan dolayı dergi hakemlerine çok teşekkür ederiz. 


\section{KAYNAKLAR (REFERENCES)}

[1] Yenilenebilir Enerji Kaynaklarının Elektrik Enerjisi Üretimi Amaçlı Kullanımına İlişkin Kanun (Kanun no. 5346). Resmi Gazete, 25819, (2005).

[2] http://data.iea.org/, Erişim Tarihi: 06.05.2016.

[3] http://www.gwec.net/wp-content/uploads/vip/GWECPRstats-2015_LR.pdf, Erişim Tarihi:12.05.2016.

[4] T.C. ETKB, Enerji İşleri Genel Müdürlüğü, 2014 Yılı Denge Tablosu, 13.11.2015.

[5] http://www.teias.gov.tr/YukTevziRaporlari.aspx, Erişim Tarihi:04.04.2016.

[6] T.C. ETKB, Nükleer Santraller ve Ülkemizde Kurulacak Nükleer Santrale İlişkin Bilgiler, Nükleer Enerji Proje Uygulama Dairesi Başkanlığı, Yayın No. 2.

[7] Aras, H., "Wind energy status and its assessment in Turkey”, Renewable Energy, 28, 14:2213-2220, (2003).

[8] Elektrik Piyasası Kanunu (Kanun no. 4628). Resmi Gazete, 24335, (2001).

[9] Elektrik Piyasası Kanunu (Kanun no. 6446). Resmi Gazete, 28603, (2013).

[10] TÜREB (Türkiye Rüzgâr Enerjisi Birliği), Türkiye Rüzgâr Enerjisi İstatistik Raporu, (2016).

[11] http://www.mgm.gov.tr/FILES/haberler/2010/retsseminer/2_Mustafa_CALISKAN_RITM.pdf, Erişim Tarihi: 09.07.2015.

[12] http://www.ritm.gov.tr, Erişim Tarihi: 06.05.2016.
[13] Akmandor İ. S., Akgün N., Altuntaşoğlu Z.T., Malkoç Y. ve Ayaz F., "Kısa Süreli Rüzgâr Enerjisi Tahminleri ve Tahmin Sistemleri-Rüzgâr Enerjisi Tahminleri, Tahmin Sistemleri ve Değişkenliğì”, Dünya Enerji Konseyi-Türk Milli Komitesi, (2009).

[14] Terciyanlı E., Demirci T., Küçük D., Saraç M., Çadırcı I. ve Ermiş M., "Enhanced Nationwide Wind-Electric Power Monitoring and Forecast System", IEEE Transactions On Industrial Informatics, 10(2): 11711184, (2014).

[15] Elektrik Piyasası Dengeleme ve Uzlaştırma Yönetmeliği. Resmi Gazete, 27200, (2009).

[16] Camadan E. and Erten I.E., "An evaluation of the transitional Turkish electricity balancing and settlement market: Lessons for the future", Renewable and Sustainable Energy Reviews, 15: 1325-1334, (2011).

[17] Yenilenebilir Enerji Kaynaklarının Belgelendirilmesi ve Desteklenmesine İlişkin Yönetmelik. Resmi Gazete, 28782: (2013).

[18] https://rapor.epias.com.tr/rapor/, Erişim Tarihi: 01.01 .2016

[19] http://www.epdk.org.tr/index.php/elektrikpiyasasi/yekdem, Erişim Tarihi: 31.12.2015.

[20] http://www.epdk.org.tr/TR/Anasayfa, Erişim Tarihi: 12.05.2016.

[21] Yenilenebilir Enerji Kaynaklarının Belgelendirilmesi ve Desteklenmesine İlişkin Yönetmelik. Resmi Gazete, 29698:(2016). 